\title{
THE POWER OF STATE, THE RIGHT OF PARENTS, THE RIGHT OF THE CHILD - THE RIGHT TO EDUCATION AS THE RIGHT TO POSSESS CONTROL
}

\author{
Magdalena Butrymowicz*
}

\begin{abstract}
Why does the state have power in the area of education over parents' wishes? The first reason has already been explained above: these are financial and economic aspects. The second reason is of historical nature. The state has controlled education in general historically. When in the 19th century the idea of public schools was created, the state sponsored such schools. Private schools were in a good condition, since they had their own sponsors or proceeds from pupils' tuitions. When they lost their self-sustainability, they had to request the state for some support. And, as mentioned above, the state had its interest in controlling the educational system, because it wanted to influence the upbringing process of its citizens and create an ideology, which would help to achieve the government's goal ${ }^{1}$.
\end{abstract}

Key words: the right of parents, the right of child, the right to education

* PhD, Assistant Professor, Pontifical University of John Paul II in Krakow Faculty of Social Science.

${ }^{1}$ It is important to explain why in some parts of the paper I use interchangeably the terms state and government. When I write about general principles and the common goal of the citizens I use the word state in an abstract sense. However, when I refer to someone particular goals or interests I use the word government. 


\section{INTRODUCTION}

Education as a state obligation is a new concept in the area of law in general. The origin of this right is closely related to economic problems in the 1920s and a great depression of 1930s. The economic and financial crisis had its consequences for the society and state regimes. For the government, public education became a useful tool used to manipulate the society and to create a society, which would follow the government's ideology.

This main reason for creating public education systems at the beginning of the 20th century played also a major role in the integration and legitimization of the political systems in various countries. In many countries, governments decided to recognize the right to education as a social benefit. One of such examples is Latin America, where education played a fundamental role in governmental social programs and was perceived as the key to create a responsible, skilled and useful citizen, committed to the state. On the other hand, education became a primary requirement on the labor market, demanded both by employees and hiring companies ${ }^{2}$. Taking this factor into account, from the state's perspective, public education could be perceived as a powerful tool to consolidate the nation and the market. Another important role of public education was to legitimatize the state's existence, since education contributes to the state hegemony. One of the examples of such synergy is Italian universities. Historically, universities were perceived as autonomous bodies, independent from state influences, but, in fact, nowadays universities rely on state subsidies. Being paid by the state means some degree of dependence on the state. On the other hand, universities provide qualified workforce to the state, who work in governmental offices, so the state benefits from their university education, which has an impact on state development and integral consolidation $^{3}$. An example here can be Jamaica, where in the 19th century the state was not interested in developing education for masses, due to the fear

\footnotetext{
${ }^{2}$ C. A. Torress, A. Puiggros, Latin American Education, Oxford 1997, pp. 5-7.

${ }^{3}$ Ibidem, pp. $220-227$.
} 
that ex-slaves' children could gain control over the government ${ }^{4}$. In the European countries, the state control over the educational system can be observed to a high extent. We can read in Polish newspapers about parents who oppose school shutdown or about the planned reform of the educational system structure. To some extent, it is up to the governing party to decide what educational system the country will have ${ }^{5}$.

The third and the most important reason why the state is responsible for the educational system human rights. According to the international law doctrine, the state is responsible ${ }^{6}$ for the human rights protection mainly on its territory and in the international sphere, and one of those rights is the right to education ${ }^{7}$. In Article 26 of the Universal Declaration of Human Rights we can read not only that we have the right to education, but also that such education should be free and that parents have the priority in the area of education over the state ${ }^{8}$. Thus, the Declaration gives parents the power to decide about their children's education over the state. However, when reading carefully the Declaration, we realize that the state has control over parents. Why is that so? Because education is compulsory, as we can read, and the state is obliged to secure this right. The parents regain their power if they have money to send their children

${ }^{4}$ M. Whyte, A short history of education in Jamaica, London 1977, pp. 80-95.

${ }^{5}$ Partners: Poland, http://www.partners-in-education.com/pages/poland/The_Polish_School_System.html, [date of access: 20.1.2017].

${ }^{6}$ J. Ruggie, Report of the Special Representative of the Secretary General on the issue of human rights and transnational corporations and other business enterprises, A/HRC/17/3, pp. 3-4.

${ }^{7}$ G. Quinn, A. Arstein-Kerslake, Restoring the 'human' in 'human rights': personhood and doctrinal innovation in UN disability convention. [in:] C. Gearty, C. Douzinas, Human Rights Law, Cambridge 2012, pp. 45-47.

${ }^{8}$ Article 26. (1) Everyone has the right to education. Education shall be free, at least in the elementary and fundamental stages. Elementary education shall be compulsory. Technical and professional education shall be made generally available and higher education shall be equally accessible to all on the basis of merit. (2) Education shall be directed to the full development of the human personality and to the strengthening of respect for human rights and fundamental freedoms. It shall promote understanding, tolerance and friendship among all nations, racial or religious groups, and shall further the activities of the United Nations for the maintenance of peace. (3) Parents have a prior right to choose the kind of education that shall be given to their children. United Nations General Assembly, The Universal Declaration of Human Rights, Paris on 10 December 1948. 
to a private school. In fact, this is the only way for them to exercise the right mentioned in the Declaration regarding decisions about their children's education. If they do not have enough funds, they are dependent on the state and the state will make them send their children to a school controlled by the state.

When analyzing parents' rights and the state's rights, the children's interest must not be forgotten. On the one hand, parents have a right to decide about their children's education and, on the other, the state is obliged to provide all children with access to education. The problem arises when we ask about children's rights and benefits. What happens, if, at some point, the child's needs or will are not the same as his/her parents' needs or will? Or when the parents and their child acting together do not follow the compulsory education pattern at the basic leve? have the right to act against parents' wishes, but according to their child's will? Or does it have the right to make both the parents and their child to act according to the state policy?

In this respect, the right to education is indeed a complex problem. On the one hand, it is a right and, on the other hand, it is an obligation and thus a powerful tool in the state's or parents' hands.

\section{CONCEPT OF SPECIAL CHILDREN'S RIGHTS}

The idea of human rights is derived from ethical norms and natural law ${ }^{10}$. At the beginning, they were the sole domain of legal scholars, who not only developed an ideology behind natural law, but also tried

${ }^{9}$ The story of Laura Dekker can be recalled here. A 13-year old Danish girl who wants to sail around the world and skips her school term, B. Waterfield, Dutch court stops girl, 13, sailing round world, The Telegraph, 28 Aug 2009, http://www.telegraph.co.uk/news/ worldnews/europe/netherlands/6106182/Dutch-court-stops-girl-13-sailing-round-world. html, [date of access: 10.02.2017].

${ }^{10}$ This concept is criticized by some scholars, however, in the European approach to the human rights it has great importance to understood the roots of the human rights and the obligation coming from the state when it comes to human rights. C. F. Alford, Narrative, nature and the natural law, New York 2010, pp. 2-5. 
to exercise human rights against the state in courts. However, as the time passed by, pedagogical, psychological, anthropological and ethical sciences became interested in human rights. Ethical norms became the concept through which human rights law is justified, interpreted and extended. According to Clark Buttler ${ }^{11}$ and Michael Freeman ${ }^{12}$, generally, it was the main reason why the United Nations introduced the human rights concept into international law: human rights were so much rooted in the ethical and philosophical sphere that it was a natural move ${ }^{13}$. Nowadays, there is a vast array of United Nations' instruments which protect human rights and which are designed specifically to protect particular rights. Protection of children's rights became of special importance, due to several reasons. The first one was the actions taken by some organizations or individuals, which insistently tried to disturb children's wellbeing or even treat children not as human beings but as a kind of merchandise. This may sound as an exaggeration and some people would stress that nowadays children are much better protected than in the past decades. To some extent it is true, but, on the other hand, presently we may observe new trends which have never existed before. Besides, there are still countries where children's rights are not protected and children suffer huge damage, not only physically, but, which is worse, in the emotional sphere. Taking the foregoing into account, it is important to check how the international society protects children, what steps are taken to secure minors' rights and what instruments can be applied to protect children's dignity and self-esteem. What is important, effective protection of children's rights cannot be achieved unless substantive protective measures are perceived by local communities as culturally legitimate. On the other hand, implementation procedures are aimed at enhancing such legitimacy, as opposed to merely ensuring adherence to them.

The beginning of the ideology of protecting children's rights can be dated back to the 19th century and it is connected with the story of a young, 8-year-old girl called Mary Ellen McCormack. She was abused by her fos-

${ }^{11}$ C. Butler, Children Rights: Movement, International Law, and Opposition, West Lafayette 2012, p. 1.

${ }^{12}$ M. Freeman, The Future of Children's Rights, Volume 14, Issue 4, Pages 229-325.

${ }^{13}$ Ibidem, p. 1. 
ter mother and her case brought to the court by the American Society for the Prevention of Cruelty to Animals became the first case in United States which put the human face on abuse of children ${ }^{14}$. The next two important figures on the children's rights radar include: a Polish pedagogist and writer Janusz Korczak and Brit Eulantyne Jebb, who drafted the first Declaration of the Rights of the Child and lobbied at the end of the First Word War in favour of its adoption by the League of Nations. In 1919, Jebb founded also the Save the Children Fund, which was specifically designed to protect children, who were war victims. The League of Nations, after a long discussion, finally adopted the first declaration of the Rights of the Child in $1924^{15}$. The next step in the child's rights movement was the adoption, in 1959, of the United Nations Declaration of Human Rights and supplements to it, including the provisions recognising disable children's needs for special protection against neglect and employment detriment ${ }^{16}$. This leads us to the most important legal document in the children rights history, namely, the Convention on the Rights of the Child.

The United Nations Convention on the Rights of the Child (1989) is the most important piece of international law concerning children. Other significant international instruments regarding children's rights are the following: the United Nations Committee on the Rights of the Child ${ }^{17}$, the United Nations Standard Minimum Rules for the Administration of Juvenile Justice ('Beijing Rules'), introduced in 1985, the United Nations Rules for the Protection of Juveniles Deprived of their Liberty ('Havana Rules'), introduced in 1990, the United Nations Guidelines for the Prevention of Juvenile Delinquency ('Riyadh Guidelines'), introduced in 1990, Guidelines for Action on Children in the Criminal Justice System

${ }^{14}$ H. Markel, Case Shined First Light on Abuse of Children, The New York Times, December 15, 2009, p. D5.

${ }^{15}$ M. Goodhart, Human Rights: Politics and Practice, Oxford 2013, p. 198.

${ }^{16}$ V. Pupavac, Children's Human Rights Advocacy, in ed. M. Goodhart, Human Rights: Politics and Practice, Oxford 2013, pp. 199 - 200.

${ }^{17}$ Created under the article 43 of the Convention on the Rights of the Child, is one of the eight UN treaty bodies, it consist of 18 independent experts responsible for monitoring the implementation of the Convention by its State parties. Committee on the Rights of the Child, http://www.ohchr.org/EN/HRBodies/CRC/Pages/CRCIntro.aspx, [date of access: 28.11.2016]. 
(Annex to UN Resolution 1997/30 - Administration of Juvenile Justice ('Vienna Guidelines'), introduced in 1997, and the United Nations Common Approach to Justice for Children passed in $2008^{18}$. The main scope of all these instruments is to secure, to all children, the right and opportunities to survive, grow and develop, within the context of physical, emotional and social well-being, for each child, up to its full potential. However, this is only the goal, whereas the reality is different. In General Comment no. 10 dated on 25 April 2007, the Committee on the Rights of the Child argues that state parties do not take necessary measures to ensure that all children are treated equally, especially children from vulnerable groups such as street children, children with disabilities and children in conflict with law. Such discrimination can be reported especially when they try to get access to education, although they should be guaranteed equal access to education as they peers. States are obliged to take all necessary steps to secure all children's rights ${ }^{19}$, but the question arises: how are children perceived by law, how does law treat them, and are they all really equal before the law?

3. CHILD'S PERCEPTION BY LAW: QUASI-PROPERTY, AN ECONOMIC ASSET, HUMAN OR A PARTLY HUMAN?

For centuries children were perceived by their families as their economic asset, especially a girl was expected to marry a wealthy man and, many a times, to pay for their parents' living. A similar attitude, with regard to covering parents' expenses, was expected from boys. From the child's birthday (sometimes even earlier), parents carefully calculated the investments in their children's education in this same way as if these were market investments. The father possessed total power over his children

${ }^{18}$ Child Rights and International Legal Framework, http://www.unicef.org/tdad/ index_56386.html [date of access: 23.12.2014].

${ }^{19}$ Committee on the Rights of the child, General Comment No. 10 (2007) Children's rights in juvenile justice, Geneva 2007, pp. 4-5. 
under the ancient Roman law ${ }^{20}$, and the children were considered a part of their father's property, with his power over their life and death ${ }^{21}$, Later in history, children were perceived as small adults, they dressed like adults, but they were denied the right to speak freely ${ }^{22}$. Jean Jacob Rousseau, in Emile, described children (the state of infancy) as the beginning of the man. According to him, every child is born weak, destitute of all things, stupid and needing an assistant. He developed the need of bringing up children properly, where the mother plays the prevailing role, and the outcome of her activities is the creation of a strong and wise adult ${ }^{23}$. It was Rousseau who first wrote that the child is vulnerable at the moment of birth, and the only way it can express itself is through crying, as the way of complaining ${ }^{24}$. Through centuries this approach to the child was ill-defined and finally a negative definition was widely accepted that the child is not yet an adult ${ }^{25}$. This definition, first accepted in English speaking countries, is now widely recognized. In the contemporary world, the legal definition of the child was developed, and according to Art. 1 of the Convention on the Right of the Child: a child means every human being below the age of eighteen years unless, under the law applicable to the child, majority is attained earlier ${ }^{26}$. It is necessary to add that children are different from adults in their physical and psychological development, so they need a special approach, and special treatment ${ }^{27}$.

${ }^{20}$ B. W. Frier, Th. A. J. McGinn, A Casebook on Roman Family Law, Oxford 2004, p. 109.

${ }^{21}$ C. Butler, Child Rights: The Movement, International Law, and Opposition, West Lafayette 2012, p. 13.

22 Ibidem.

${ }^{23}$ J.J. Rousseau, Emile or concerning the education, Boston 1889, p. 13.

${ }^{24}$ Ibidem, pp. 17-19.

${ }^{25}$ Van Bueren G., The International Law on the Rights of the Child, The Hague 1998, pp. 33-34.

${ }^{26}$ Convention on the Rights of the Child adopted and opened for signature, ratification and accession by General Assembly's Resolution 44/25 of 20 November 1989, entered into force on 2 September 1990, in accordance with Article 1, http://www.ohchr.org/EN/ ProfessionalInterest/Pages/CRC.aspx

${ }^{27}$ Committee on the Rights of the child, General Comment No. 10 (2007) Children's rights in juvenile justice, Geneva 2007, p. 5. 
One important remark should be added at this point. In some countries, especially in Europe and Asia, children are treated as a quasi-property of their parents. A parent, based on his/her biological ties to the child, wants to have full rights to his/her children. A milestone against this approach took place in the Kingsley v. Kingsley case in the United States. On July 21, 1992, an eleven-year-old boy, Gregory, was granted the right to fill the petition for termination of the parental rights of his natural parents ${ }^{28}$. The boy's mother petitioned otherwise, but she lost the case, and Gregory terminated his relation with his biological parents ${ }^{29}$. In legal literature, this case is perceived as the end of the era when the child is perceived as his/her parents' property. Rachel, a biological mother of Gregory, argues that: "this procedure resulted in unduly placing upon her the burden to overcome this comparison, which resulted in an interference with her fundamental liberty interest in Gregory's care, custody, and maintenance." The court replies that: "termination of parental rights requires a two step analysis. First, did the parents do something that the State has determined to be sufficiently egregious to permit forfeiture of their right to continue as parents (abuse, neglect, abandonment, voluntary consent to adoption)? Unless the answer to this first question is affirmative, the second step is the analysis (the best interest of the child)" ${ }^{30}$. On the other

${ }^{28}$ At this time there were a number of cases which denied the children's right to sue, unless he or she acted by his guardian or parents: Keehn v. Joseph C. Mackey \& Co., 420 So.2d 398, 399 n. 1 (Fla. 4th DCA 1982); Argonaut Insurance Co. v. Commercial Standard Insurance Co., 380 So.2d 1066, 1067 (Fla. 2d DCA), rev. denied, 389 So.2d 1108 (Fla. 1980); General Development Corp. v. Kirk, 251 So.2d 284, 286 (Fla. 2d DCA 1971); Earls v. King, 785 S.W.2d 741, 743 (Mo. Ct. App. 1990); Parker v. Bowron, 40 Cal.2d 344, 254 P.2d 6, 9 (1953); 59 Am.Jur.2d Parties $\$ \$ 24,30$ (1987). See also Moorhouse v. Ambassador Insurance Co., 383 N.W.2d 219 (Mich. Ct. App. 1985). Kingsley v. Kingsley, so.2d 780 (1993).

${ }^{29}$ Appeal court in his judgment said: "trial court is authorized to terminate a natural parent's rights only if the trial court finds by clear and convincing evidence that termination is in the manifest best interests of the parent's child and that the parent has abandoned, abused, or neglected the child”. Kingsley v. Kingsley, so.2d 780 (1993).

${ }^{30}$ On the other hand court said that: "While the child has the right not to be abused, neglected or abandoned, there is no right to change parents simply because the child finds substitutes that he or she likes better or who can provide a better standard of living".). Kingsley v. Kingsley, so.2d 780 (1993). 
hand, the appeal showed that the trial judge made a mistake by allowing Gregory to fill the petition, but the decision was not reversed, due to the harmless error in the law. The analyses of this proved that for the judge it was unimportant that Gregory's biological mother became an alien person to him from the legal perspective. Nonetheless, this case shows that the approach to children has changed and that parents cannot claim full rights over their children as their property. Their rights to children, due to the adoption of the Convention on the Right of the Child, are perceived more as an obligation towards children, where they are their children's guardians and protectors.

\section{CHILD AS THE SOLE RIGHT HOLDER}

However, it is not so simple, the convention only defined the child as a possessor of certain rights, and not the child himself/herself. Also, within the scope of the Convention, the child is perceived as a member of the family or any other social group ${ }^{31}$. So, the child is the holder of the rights and the state is declared as the protector of such rights. On the one hand, the state should take into account that children grow and mature at a different speed, and that there are certain rights that every child is born with. It can be agreed that children are entitled to a safe environment, good nutrition, healthcare, and education. On the other hand, parents have the right to raise their children as they deem fit, and if any child is not safe, the state can remove him/her from his/her home. Yet, parents are required to meet the child's basic needs and the child can exercise his/her rights against the parents ${ }^{32}$.

${ }^{31}$ S. G. Mower, The Convention on the Rights on the Child: International Law Support for the Children, London 1997, p. 4.

${ }^{32}$ Committee on the Rights of the Child, General Comment No. 10 (2007) Children's rights in juvenile justice, Geneva 2007, p. 5. 


\section{THE RIGHT TO EDUCATION IN THE UNITED NATIONS CONVENTION}

OF THE RIGHT OF THE CHILD

This differentiation is especially important when it comes to the right to education. In general, access to education is everyone's right. The right to education is a human right and was declared as a universal right in Article 26 of the Universal Declaration of Human Rights ${ }^{33}$. Johannes Morsink wrote that this particular article is the most clearly shaped by the experience of the Second World War. Explaining the reasons which led to drafting of the third and the second paragraph ${ }^{34}$, he quoted Hitler's Main Kampf and argued that the Nazis abused the state power in the field of education, since the state cannot play the role of the principal duty bearer here. It is the parents who should be the principal duty holders of their children's educational rights, while the state plays only the secondary role. The state should only help parents to fulfill their obligation in this sphere, and step in only when parents act against their children's right or cannot act at all ${ }^{35}$. The ideology behind this approach can be found in Jean Jacob Rousseau's book called Emile. He wrote that a particular father fulfilling

33 "(1) Everyone has the right to education. Education shall be free, at least in the elementary and fundamental stages. Elementary education shall be compulsory. Technical and professional education shall be made generally available and higher education shall be equally accessible to all on the basis of merit. (2) Education shall be directed to the full development of the human personality and to the strengthening of respect for human rights and fundamental freedoms. It shall promote understanding, tolerance and friendship among all nations, racial or religious groups, and shall further the activities of the United Nations for the maintenance of peace. (3) Parents have a prior right to choose the kind of education that shall be given to their children.", United Nations Universal Declaration of Human Rights, Paris on 10 December 1948.

${ }^{34}$ (2) Education shall be directed to the full development of the human personality and to the strengthening of respect for human rights and fundamental freedoms. It shall promote understanding, tolerance and friendship among all nations, racial or religious groups, and shall further the activities of the United Nations for the maintenance of peace. (3) Parents have a prior right to choose the kind of education that shall be given to their children. United Nation, Universal Declaration of Human Rights, Paris on 10 December 1948.

${ }^{35}$ J. Morsink, The Universal Declaration of Human Rights: Origins, Drafting, and Intent, Philadelphia 1999, pp. 90-91. 
his parental duties is obliged to support and educate his children. His obligation is to pass all his knowledge to his children to teach them the rules of the world and the children have the right to obtain such knowledge. When the father is incapable of doing so, he: "must charge a third person" to do it. So, the children have the right to be educated from the day when they are born, when they learn from their parents to speak, how to see or how to hold objects. Education is an investment in the child's future. According to him, parents are those who decide about their child's education, especially the father ${ }^{36}$. In Rousseau's world, the best education for a child is to let him/her be free and kindly corrected in his or her behavior. The freedom of education should allow parents to choose the best way to educate their children in contact with nature.

In the modern era, the Convention on the Right of the Child defines the child as the possessor of rights. Some children's rights are obtained as they grow, depending on their age and the level of maturity. For example, children have a limited right to free speech. In many instances, children are encouraged to form opinions and speak freely their mind. However, schools may limit the child's speech if they feel it could harm other students. This rule can be applied very differently to organizations gathering students of particular age groups. Children are not allowed to vote, hold property, consent to medical treatment, sue or be sued, or enter into certain types of contracts. In some cases, they are able to do these things, but must have a parent or a legal guardian to act on their behalf ${ }^{37}$.

6. VOTE IN THE FAVOR OF EDUCATIONAL FREEDOM FOR THE PARENTS

The United States have two excluding rights: the right to educational freedom and the right of the state to control schooling. Americans are determined to preserve their educational freedom, which, in their opinion, helps to preserve their political freedom guaranteed in the American

${ }^{36}$ J.J. Rousseau, Emile or concerning the education, Boston 1889, pp. 20-27.

${ }^{37}$ S. G. Mower, The Convention on the Rights of the Child: International Law Support for children, London 1997 pp. 4-5. 
Constitution. What does the educational actually freedom mean? Generally, it can be said that the educational freedom means that parents can choose the school or the educational system for their children which they think is the best for their children. For parents, it means choosing of an educational option which follows their religious and cultural traditions ${ }^{38}$. Basically, this looks extremely promising for the parents, who can pursuit their ideology in the field of their children's education, without any state influence. Taking this approach into account, educational freedom means not only the right to choose school, but also the right to bring up children according to particular values and traditions followed by their parents. This leads to the creation of different types of school in one country: religious schools, French schools, Polish schools, English schools, state and private schools. The existence of all these different types of schools allows parents to freely choose the type of school which follows their educational model. The reality has proven this statement to be wrong. An example, though not very scientific, can be the movie titled Dangerous Minds, about a public school for dangerous and neglected teenagers ${ }^{39}$. There is a risk in the educational freedom, which appears in those systems, when the state has too much influence on the school system, and in fact, parents have no other option but to choose a state school ${ }^{40}$. This is a serious risk to the parents' freedom. The power of the state was widely recognized by different kinds of dictators or autocracies in the world history. The Jacobins can be recalled, a representative of whom, Danton, said: "...that children must suck republican milk. The Republican is one and indivisible; public instruction must also be related to this center of unity" ${ }^{41}$. A similar approach was adopted by communists in Eastern Europe. By closing all private schools and forcing parents to send their children to public schools only one educational program was allowed: the one which supported communist values and historic interpretations. This caused a huge gap between three generations in Poland: those who were educated before the Second

${ }^{38}$ M. Gryphon, E. A. Meyer, Our History of Educational Freedom, What it Should Mean for Families Today, Policy Analysis, no. 492, October 8, 2003 p. 2.

${ }^{39}$ Dangerous Minds, http://www.imdb.com/title/tt0112792/, [date of access: 10.02.2017].

${ }^{40}$ Ch. L. Glenn, Educational Freedom in Eastern Europe, op. cit. pp. 5-9

${ }^{41}$ Ibidem p. 11 
World War, those educated by the communists and those educated after the fall of Berlin Wall. This had been proved previously that if the educational freedom is not guaranteed, the society cannot exercise its democratic rights and freedoms ${ }^{42}$.

Henryk Samsonowicz, in his book "Dziedzictwo Średniowiecza, Mity i rzeczywistość" [Heritage of the Middle Ages. Myths and Reality] presents a lot of examples showing how the state manipulated historical facts in the educational process in order to create its own historical reality. One of notable examples is the use of historic figures as role models in primary school books at the beginning of the 20th century, absolutely against historical and archeological facts ${ }^{43}$. Next, he proves that such an approach was deliberate on the part of the state, which wanted to explain reality through the past and to create a new ideology and a society paradigm. Interestingly, he presents similar attitudes in other European countries, for example, England or Germany ${ }^{44}$. Thus, the state uses education to built the model of the society, which is appreciated by governing parties. Such influence is highly dangerous, as it weakens the democratic foundation of the state. Another negative example of the restriction of the educational freedom can be seen, paradoxically, in the United State of America. First of all, in the US, since the beginning of the foundation of the American democra$c y$, the education freedom has been perceived through the rights existing in protestant religious schools. Charles Glenn, a professor of Educational Leadership and Development and the former Dean of the School of Education at Boston University argues that school choice is a luxury for most American families, that parents should have the right to make a decision about the school their children would attend, and they should not pay any financial penalty ${ }^{45}$. A similar statement can be read in the US Supreme

${ }^{42}$ Ibidem, pp. 6-12

${ }^{43}$ According to Samsonowicz, the historical reality in this period was explained by historical facts and figures. In England, for example, King Arthur used modern language and phraseology to refer to political reality.

${ }^{44}$ H. Samsonowicz, "Dziedzictwo Średniowiecza, Mity i rzeczywistość”, Wrocław 2009, pp. 28-31.

${ }^{45}$ Ch. Glenn, Why America is behind Europe on educational freedom, December 22, 2015, https://www.redefinedonline.org/2015/12/why-america-is-behind-europe-on-educational-freedom/, [date of access: 11.12. 2016]. 
Court's decision in the Zelman v. Simmons-Harris case ${ }^{46}$, where court supported the thesis that educational freedom and the parents' right to choose the school program is constitutionally guaranteed to parents. The court also decided that the state should support the parents' freedom in school choice by creating such an opportunity for them that will be available to a broad group of beneficiaries ${ }^{47}$. So, the program should not favor only one group of schools, i.e. religious schools, as was argued in this case, but the state should make sure that parents have adequate educational options ${ }^{48}$.

\section{VOTE AGAINST EDUCATIONAL FREEDOM}

Once agreed that parents should have the right to educational freedom, we need to look at the state side, where the state is obliged, by its social duties, to the society and the international law, to protect the right to education as a human right ${ }^{49}$. The state is obliged to guarantee education at the primary level as compulsory and cost free ${ }^{50}$.

The United Nations Convention of the Right of the Child is one of the most important international pieces of legislation within the scope

46 "...The State of Ohio has established a pilot program designed to provide educational choices to families with children who reside in the Cleveland City School District. The question presented is whether this program offends the Establishment Clause of the United States Constitution. We hold that it does not.", Zelman v. Simmons-Harris, (001751) 536 U.S. 639 (2002) 234 F.3d 945, reversed.

47 "The First Amendment begins with a prohibition, that "Congress shall make no law respecting an establishment of religion," and a guarantee, that the government shall not prohibit "the free exercise thereof." These Clauses embody an understanding, reached in the 17th century after decades of religious war, that liberty and social stability demand a religious tolerance that respects the religious views of all citizens, permits those citizens to "worship God in their own way," and allows all families to "teach their children and to form their characters as they wish." Zelman v. Simmons-Harris, (00-1751) 536 U.S. 639 (2002) 234 F.3d 945, reversed.

${ }^{48}$ M. Gryphon, E. A. Meyer, Our History of Educational Freedom, What it Should Mean for Families Today, Policy Analysis, no. 492, October 8, 2003 p. 13.

${ }^{49}$ Donders Y., Volodin., V. (ed.), Human Rights in Education, Science, and Culture: Legal Developments and challenges, Bodmin 2008, p. 184.

${ }^{50} \mathrm{M}$. Verheyde, Article 28: The Right to Education, p. 55 
of children's rights. It is also the only document which was adopted and ratified by almost all states in the world. The authors of the Convention made an attempt to regulate almost all spheres of children's rights, especially education. Remembering the background of the educational rights in the UN Declaration of Human Rights, we can simply say that the same scopes were behind this Convention. Thereafter, according to Art. 28 of the Convention on the Rights of the Child: "States Parties recognize the right of the child to education, and with a view to achieving this right progressively and on the basis of equal opportunity, they shall, in particular: make primary education compulsory and available free to all; encourage the development of different forms of secondary education, including general and vocational education, make them available and accessible to every child, and take appropriate measures such as the introduction of free education and offering financial assistance in case of need; make higher education accessible to all on the basis of capacity by every appropriate means; make educational and vocational information and guidance available and accessible to all children; take measures to encourage regular attendance at schools and the reduction of drop-out rates. States Parties shall take all appropriate measures to ensure that school discipline is administered in a manner consistent with the child's human dignity and in conformity with the present Convention. The States Parties shall promote and encourage international cooperation in matters relating to education, in particular, with a view to contributing to the elimination of ignorance and illiteracy throughout the world and facilitating access to scientific and technical knowledge, as well as modern teaching methods. In this regard, particular account shall be taken of the needs of developing countries" 51 . The right to education in the Convention meaning is divided into two parts: firstly, as the right to cost free education and, secondly, to compulsory primary education. Article 28 contains also other factors important in exercising educational rights, such as rights to special facilitates for disabled people and those with learning difficulties or for the children who, without such facil-

${ }^{51}$ Convention on the Rights of the Child adopted and opened for signature, ratification and accession by General Assembly's Resolution 44/25 of 20 November 1989, entered into force on 2 September 1990, in accordance with Article 49, http://www.ohchr.org/EN/ ProfessionalInterest/Pages/CRC.aspx. 
ity, would not have any access to education ${ }^{52}$. So, the state is liable for the quality of education and for guaranteeing access to education to everyone. The above-quoted Convention clearly emphasizes the state's obligation, as opposed to the parents' rights. In this respect, the state not only has an obligation to act in children's favor, but also to secure their interest. The state has the right to implement its own internal policy and affairs totally independently from external influence. Such right also means creation of its own educational policy and the school system. In general, it is up to the state to decide whether educational freedom would be guaranteed to the citizens or not. The question is whether the international community can force a sovereign state to follow the Convention and grant parents full educational freedom. There are two ways of answering this question. The first question has been already answered, the second problem is based on the presumption of the state's independence and the answer is negative. The state will argue against such an attempt, however, on some occasions, the state will not want to be perceived as the rights breaker and can follow international law when it comes to human rights ${ }^{53}$. Also, as has been said above, in some respects, the educational freedom can be in opposition to the state's interests. The question to be asked now is whether the state has any right to interfere and breach the parent's educational freedom. Brown or Beitz would never allow the state to act against their citizens' wishes arguing that the main reason of the state's existence is to take care of its citizens' welfare. So the state acts as a local agent, the mother or the father of its citizens ${ }^{54}$. Even this theory will not support the state's obligation to guarantee parents full educational freedom. First of all, the view of welfare or the common interest of the citizens can be perceived from different, even opposite, angles. We cannot rule out that no one will argue against the state policy just because of an assumption that the state is a wrongdoer. Examples of such an attitude have been presented above.

${ }^{52}$ M. Verheyde, A Commentary on the United Nations Convention on the Rights of the Child: Article 28: The Right to Education, Leiden 2006, p. 55.

${ }^{53} \mathrm{Ch}$. Brown, Sovereignty, rights and Justice, international political theory today, Cambridge 2010, pp.7-8.

${ }^{54} \mathrm{Ch}$. Brown, Sovereignty, rights and Justice, international political theory today, Cambridge 2010, pp. 80-81. 
So, the state is entitled to protect its sovereignty and each state has the same capacity and independence to make decisions about its internal concept of good. Robert Mccorquodale argues otherwise when it comes to the human rights law regime. According to him, in the modern era, the state has lost its internal freedom in the human rights area, because the international human rights system, especially courts will make states follow international court judgments in cases of human rights breach ${ }^{55}$. This will be true only if we add that the state must be willing to follow such court judgments, if not, there are no instruments ${ }^{56}$ to force the state to do so. One of such examples is Poland, which lost a few cases regarding the right to legal abortion in the European Court of Human Rights, but despite the court's order to change internal law, nothing has been done in this respect ${ }^{57}$. The same applies to the right to educational freedom.

\section{BATTLEGROUND}

The analysis of the state's and parents' rights in the field of education shows clearly that both parties can act against each other, and even opposite each other. The state has an interest in controlling education and parents have the same goals as the state. Both can act against the child's benefits, but in favor of their well-argued interest. At the international level, both parties have similar controlling rights, with stress put on the parents' rights as primary, and the state as a substitute, when parents fail. We have already agreed that the state should act as an educational guard. However, it can happen that parents entrust their children's education to the state and the state fails. In such situation, the parents once again act against the state, because a major argument in favor of some state control over the education is its accessibility to all children, especially to those who cannot afford private education. It is also the state's obligation to provide education at

${ }^{55}$ M. D. Evans ed., International law, Oxford 2010 pp. 290 - 291.

${ }^{56}$ Besides war and external intervention of course.

${ }^{57}$ European Court of Human Rights, Case of P. and S. v. Poland (application no. 57375/08), Judgment 30 October 2012 Strasbourg . 
a certain level and to grant all children this same opportunity in the future. On March 20, 2007, the District Court of Georgia ordered the Atlanta Independent School System to pay Jarron Draper's tuition in a private special education school for four years, or until he completed high school with a diploma, as prospective compensatory education for their persistent failure to educate him $^{58}$. In this case, the US Appeal Court decided that the state failed its obligation concerning Draper's education, and that is why, it ordered financial compensation and the obligation to cover his private school tuition. So, in this case, the court was clear that the state had an obligation to take all necessary steps not only to guarantee a certain level of education for Draper, but also when the state failed, the child had the right to be refunded. The District court "... found that the School System failed to provide Draper with "the basic floor of opportunity" 59 .

The second battlefield is when parents fail. It is generally recognized by the scholars that the family possesses some kind of autonomy, free from state intervention, and there are parents who are decision makers in the family. So, the parents have authority over their children and make decisions on their behalf. However, parents' power is not absolute. The state has the right to interfere when parents neglect their duties ${ }^{60}$. In some constitutions, for instance, in the Irish constitution, the state's role is recognized as a supporting role, whereas parents clearly play the main role. The situation changes when parents neglect their obligation ${ }^{61}$.

${ }^{58}$ Draper v. Atlanta Indep. School Sys., 518 F.3d 1275,1290 (11th Cir. 2008).

${ }^{59}$ Citt. Draper v. Atlanta Indep. School Sys., 518 F.3d 1275,1290 (11th Cir. 2008).

${ }^{60}$ O. Doyle, Family Autonomy and Children's Best Interests: Ireland, Bentham, and the Natural Law, International Journal of the Jurisprudence of the Family, Vol. 1, pp. 55-56.

${ }^{61}$ Article 42 (1) The State acknowledges that the primary and natural educator of the child is the Family and guarantees to respect the inalienable right and duty of parents to provide, according to their means, for the religious and moral, intellectual, physical and social education of their children. (2) Parents are free to provide this education in their homes or in private schools or in schools recognized or established by the State. (3.1) The State may not oblige parents in violation of their conscience and lawful preference to send their children to schools established by the State, or to any particular type of school designated by the State. (3.2) The State, however, as guardian of the common good, requires in view of actual conditions that the children receive a certain minimum education, moral, intellectual and social. (4) The State provides for free primary education and endeavors to supplement and give reasonable aid to private and corporate educational initiative, and, 
The third battlefield is children's wellbeing. Parents' right to decide about their children's education is not an absolute right, because it is the state which decides about the range and power of this right. But parents have the right to bring up their children according to their beliefs, tradition and culture. In state constitutions, the authorities have decided that, in general, parents are liable for their children's education. The same authorities also decide that the state is responsible for determining the meaning of this right ${ }^{62}$. The fundamental right of the state to act when the child's wellbeing and the best interest is in danger is not the question right now. The following question is much more important: what does the wellbeing of the child mean? And the child's best interest. Looking once again at the Constitution of Ireland or the Constitution of Poland ${ }^{63}$, it can be seen that both constitutions draw from fundamental natural law and teaching of the Catholic Church. The Constitution of the Islamic Republic of Iran, adopted on 24 October $1979^{64}$, is written within the scope of the muslin law and Islamic principles ${ }^{65}$. In both situations, the state's understanding of the child's wellbeing and best interest in the area of education, can be perceived in totally different ways. What happens

when the public good requires it, provide other educational facilities or institutions with due regard, however, for the rights of parents, especially in the matter of religious and moral formation. (5) In exceptional cases, where the parents for physical or moral reasons fail in their duty towards their children, the State as guardian of the common good, by appropriate means endeavors to supply the place of the parents, but always with due regard for the natural and imprescriptible rights of the child. Constitution of Ireland, 29 ${ }^{\text {th }}$ December 1937.

${ }^{62}$ O. Doyle, Family Autonomy and Children's Best Interests: Ireland, Bentham, and the Natural Law, International Journal of the Jurisprudence of the Family, Vol. 1, pp. 61-62.

${ }^{63}$ The Constitution of the Republic of Poland of 2nd April, 1997, DZ.U. No. 78, Item 483.

${ }^{64}$ Constitution of the Islamic Republic of Iran Adopted: 24 October 1979, https:// faculty.unlv.edu/pwerth/Const-Iran(abridge).pdf.

${ }^{65}$ The Constitution of the Islamic Republic of Iran advances the cultural, social, polit$\mathrm{ical}$, and economic institutions of Iranian society based on Islamic principles and norms, which represent an honest aspiration of the Islamic Ummah [community]. This aspiration was exemplified by the nature of the great Islamic Revolution of Iran, and by the course of the Muslim people's struggle, from its beginning until victory, as reflected in the decisive and forceful calls raised by all segments of the populations. Constitution of the Islamic Republic of Iran adopted on 24 October 1979, https://faculty.unlv.edu/pwerth/ConstIran(abridged).pdf, [date of access: 24.01.2017]. 
if Catholic parents residing in Iran want to have Catholic education for their children? Or Islamic parents in Poland wanting Islamic education for their children? It has been stated in a few places in this article that the state is interested in influencing the children's education, because school is the best way to transfer values to the next generation, shape behaviors and influence the future decision making process ${ }^{66}$.

The oposite to this statement is European Court of Justice declaratiovn that state has an obligation to guarantee that the school environment is free from any pressure that may amount to indoctrination of children ${ }^{67}$. According to court, state should acknowledge pupils rights to express their beliefs and values in the way they genuinely thought $\operatorname{proper}^{68}$. Whenever it is true, the problem is not in the clasroom decration how it was in Lautis case or in school uniforme (Regina)

The four battlefield is when state fail. This can be clearly see in the case of Çam v. Turkey, when Turkish National Music Academy rejected the Çam request for enrolment due to her bliddnes. In its final rulling the European Court of Human Rights states that in a democratic society right to education is indispensable to the furtherance of human rights and plays a fundamental role. The education is one of the most important public services in a modern state. In court opinion decidion how to regulate access to education, is a state right, but state must strike a balance between, on the one hand, the educational needs of those under its jurisdiction and, on the other, its limited capacity to accommodate them. What is the most important, unlike some other public services, education is a right that enjoys direct protection under the international law ${ }^{69}$.

${ }^{66}$ C. Garcimartin, Education in the Secular State: whose Right is it, International Journal of the Jurisprudence of the Family, vol. 2, 2011, pp. 79.

${ }^{67}$ Lautsi: A Commentary on a decision by the ECtHR Grand Chamber, International Journal of Constitutional Law, Volume 11, Issue 1, 1 January 2013, Pages 218-229, https://doi.org/10.1093/icon/mos008.

${ }^{68}$ SB, Regina (on the Application of) v Denbigh High School: CA 2 Mar 2005 . [2005] EWCA Civ 199, Times 04-Mar-2005, [2005] 1 WLR 3372.

${ }^{69}$ European Court of Human Rights, case of Çam v. Turkey application no. 51500/08), Judgment (merits and just satisfaction), Court (Second Section) 23/02/2016. 


\section{THE RIGHT OF THE CHILD}

A general, a dispute at the legal level exists between parents and the state, but the children's voice is not heard. Article 12 of the Convention ${ }^{70}$ grants children the right to be heard, but does it also mean the right to make decision about their rights? Definitely not, the right to be heard is generally the right to express one's own opinion or to present one's statements. It is also important to recognize that children are completely dependent on adults' support and when abandoned, they are left with nothing to live on ${ }^{71}$. So, does the children's voice matter? Article 28 and Article 12 are closely linked to each other. The right to demand to have equal access and equal quality of education expresses the right to education ${ }^{72}$. Under Article 28, the child is the only right holder of the right to education and, in the same way, he/she is the only beneficiary of educational rights. Being the right holder, the child should have the right to express himself/ herself. Also, to better exercise this right, it is necessary to provide children with the right to be heard and to express themselves. Children should be involved in the educational process and influence $\mathrm{it}^{73}$. When we guarantee children the right to be heard in the area of education, we will solve the above-described problem ${ }^{74}$. This construction allows saying that parents are not guaranteed to choose freely the educational system, likewise

${ }^{70}$ 1. States Parties shall assure to the child who is capable of forming his or her own views the right to express those views freely in all matters affecting the child, the views of the child being given due weight in accordance with the age and maturity of the child. 2 . For this purpose, the child shall in particular be provided the opportunity to be heard in any judicial and administrative proceedings affecting the child, either directly, or through a representative or an appropriate body, in a manner consistent with the procedural rules of national law.

${ }^{71}$ G. Lansdown, Every child's right to be heard, London 2011, pp. 10-17.

${ }^{72} \mathrm{M}$. Verheyde, A Commentary on the United Nations Convention on the Rights of the Child Ser. A Commentary on the United Nations Convention on the Rights of the Child, Article 28: The Right to Education (1), published BRILL 2005, p. 11.

${ }^{73}$ G. Lansdown, Every child's right to be heard, London 2011, p.100.

${ }^{74}$ M. Verheyde, A Commentary on the United Nations Convention on the Rights of the Child Ser. A Commentary on the United Nations Convention on the Rights of the Child, Article 28: The Right to Education (1), published BRILL 2005, pp. 57 - 58. 
the state. Both parties are limited by children as right holders. Thus, the educational system created in combination with the children's voice, and together with them, will remove all obstacles. In this sense, the state has power, parents have freedom and children have their rights.

\section{SUMMARY}

Janusz Korczak wrote that children are entitled to be taken seriously. They have the right to be treated by adults with tenderness and respect, as equals. They should be allowed to grow into whoever they were meant to be $\mathrm{b}^{75}$. Eglantyne Jebb founded The Save the Children Fund to protect them against the state and their parents. In the contemporary world, at the international level, children are granted full protection and they should fully exercise their fundamental rights. The right to education is very basic. However, children are vulnerable and dependent on adults. Thus, the state, using its power, should protect children and parents in using their freedom to control the state if it violates children's rights and parents freedom. Going futher there is state obligation to fulfil its all diuties, because as state said in the Vekc v. Bułlgaria not only to a child but also to the adults ${ }^{76}$.

\section{REFERENCES}

American International Law Cases 2009, Oxford Dictionaries Staff, New York 2010.

Beiter Klaus Dieter. 2005, The Protection of the Right to Education by International Law, Leiden.

75 S. Joseph, Janusz Korczak, http://www.korczak.org.uk/, [date of access: 11.02.2017].

${ }^{76}$ As regards the right to education, while Article 2 of Protocol No. 1 cannot be interpreted as imposing a duty on the Contracting State to set up or subsidise particular educational establishments, any State doing so will be under an obligation to ...”, European Court of Human Rights, Case of Velyo v. Bulgaria 16032/07, Judgment (Merits and Just Satisfaction), Court (Fourth Section) 27/05/2014. 
Butler Clark (ed.). 2012, Child Rights: The Movement, International Law, and Opposition, West Lafayette.

Brown Chris. 2010, Sovereignty, rights and Justice, international political theory today, Cambridge 2010.

Butrymowicz Magdalena. 2015, Children's Rights in International Law, in: The Contemporary Family: Local and European perspectives, E. Osewska, J. Stala (ed.), Kraków: wydawnictwo naukowe UPJPII.

Dangerous Minds. 2017, http://www.imdb.com/title/tt0112792/, 10.02.2017.

Donders Yvonne, Volodin Vladimir (ed.). 2008, Human Rights in Education, Science, and Culture: Legal Developments and challenges, Bodmin.

Dixon Martin, McCorquodale Robert, Williams Sarah. 2011, Cases and Materials on International Law, Oxford.

Dixon Martin 2011., Cases and Materials on International Law, Oxford.

Doyle Oran. 2010, Family Autonomy and Children's Best Interests: Ireland, Bentham, and the Natural Law, International Journal of the Jurisprudence of the Family, Vol. 1, 2010.

Evans Malcolm, Murray Rachel. 2008, The African Charter on Human and Peoples' Rights: The System in Practice Cambridge.

Farrell Martha, Erickson, Cynthia Price Cohen (ed.). 2001, Children's Rights in Education, Philadelphia.

Freeman M. , The Future of Children's Rights, Volume 14, Issue 4, Pages 229-325. Frier Bruce W., McGinn Thomas A. J. 2004, A Casebook on Roman Family Law, Oxford.

Gardner J.F. 1976, Freedom for education, Council for Educational Freedom in America.

Garcimartin Carmen. 2011, Education in the Secular State: whose Right is it, International Journal of the Jurisprudence of the Family, vol. 2, 2011.

Goodhart Michael. 2013, Human Rights: Politics and Practice, Oxford.

Grover S. C. 2015, Children Defending their Human Rights Under the CRC Communications Procedure, London.

Hunter-Henin M. (ed.). 2011, Law, Religious Freedoms and Education in Europe, Farnham.

Joseph Sarah, Korczak Janusz. 2017, http://www.korczak.org.uk/, 11.02.2017. Joseph Sarah, Castan Melissa. 2013, The International Covenant on Civil and Political Rights: Cases, Materials and commentary, Oxford.

Kroczek Piotr. 2015, Religious freedom in the context of education in Poland. Relationship between Polish State and the Catholic Church, "Analecta 
Cracoviensia” 47 (2015), pp. 197-215, DOI: http://dx.doi.org/10.15633/ acr. 1757.

Kroczek Piotr. 2015, Church Teaching on Marriage and Family as an Instruction for the State Legislator in the Context of Poland, Philosophy and Canon Law vol. 1 (2015).

Kroczek Piotr. 2015, Does the Catholic Vision of the Principle of Subsidiarity Pertain to Polish Family Law? Ecumeny and Law, vol. 3 (2015).

Kroczek Piotr. 2013, Wychowanie optyka prawa polskiego i prawa kanonicznego, Kraków.

Lansdown G. 2011, Every child's right to be heard, London.

Markel H. 2009, Case Shined First Light on Abuse of Children, The New York Times, December 15, 2009.

McCaffrey Stephen, Shelton Dina, Cerone John. 2010, Public International Law: Cases, Problems, and Texts (2010), LexisNexis.

Mower A. Glen. 1997, The Convention on the Rights of the Child: International Law Support for children, London.

Office of the United Nations High Commissioner for Human Rights, Legislative History of the Convention on the rights of the child, vol 1 i vol 2, Geneva 2007.

Parkes Aisling. 2013, Children and International Human Rights Law: The Right of the Child to be Heard, New York.

Partners 2017: Poland, http://www.partners-in-education.com/pages/poland/ The_Polish_School_System.html, 20.1.2017.

Quinn G., Arstein-Kerslake Anna. 2012, Restoring the 'human' in 'human rights': personhood and doctrinal innovation in UN disability convention. [in:] C. Gearty, C. Douzinas, Human Rights Law, Cambridge.

Rousseau. 1889, Emile or concerning the education, Boston.

Ruggie J., Report of the Special Representative of the Secretary General on the issue of human rights and transnational corporations and other business enterprises, A/HRC/17/3.

Torress C. A. 1997, A. Puiggros, Latin American Education, Oxford.

Waterfield Bruno. 2009, Dutch court stops girl, 13, sailing round world, The Telegraph, 28 Aug 2009, http://www.telegraph.co.uk/news/worldnews/ europe/netherlands/6106182/Dutch-court-stops-girl-13-sailing-roundworld.html, 10.02.2017.

Van Bueren Geraldine. 1998, The International Law on the Rights of the Child, The Hague. 
Verheyde M. 2005, A Commentary on the United Nations Convention on the Rights of the Child Ser. A Commentary on the United Nations Convention on the Rights of the Child, Article 28 : The Right to Education (1), published BRILL 2005.

Verheyde M., A Commentary on the United Nations Convention of the rights of the child: Article 28: The Right to Education, Leiden 2006.

Zucca Lorenzo. 2013, Lautsi: A Commentary on a decision by the ECtHR Grand Chamber, International Journal of Constitutional Law, Volume 11, Issue 1, 1 January 2013, https://doi.org/10.1093/icon/mos008. 